\title{
PERILAKU CUCI TANGAN PAKAI SABUN (CTPS) DAN PEMANFAATAN JAMBAN PADA PENDERITA HEPATITIS A DI DESA TERBIS KECAMATAN PANGGUL KABUPATEN TRENGGALEK TAHUN 2020 \\ Lufia Prabawati, AT Diana Nerawati, Ernita Sari* \\ Jurusan Kesehatan Lingkungan Poltekkes Kemenkes Surabaya *Email korespondensi: neetaneeta07@gmail.com
}

\begin{abstract}
ABSTRAK
Kejadian hepatitis A merupakan hasil interaksi antara faktor agent, host, dan environment. Dari segi host ditunjukkan melalui perilaku cuci tangan pakai sabun (CTPS) dan perilaku pemanfaatan jamban. Perilaku CTPS di desa Terbis $64,5 \%$ dari target pencapaian $95 \%$ dan cakupan kepemilikan jamban $78,5 \%$ dengan catatan $21,5 \%$ sharing. Hasil observasi menunjukkan 2 dari 10 responden belum memiliki jamban. Penelitian ini bertujuan untuk menggambarkan perilaku CTPS dan pemanfaatan jamban pada penderita hepatitis A di Desa Terbis Kecamatan Panggul Kabupaten Trenggalek tahun 2020.

Penelitian ini bersifat deskriptif dengan melakukan observasi dan wawancara terkait dengan perilaku CTPS dan pemanfaatan jamban pada penderita hepatitis $A$. Penelitian dilakukan di Desa Terbis Kecamatan Panggul Kabupaten Trenggalek dengan menggunakan teknik purposive sampling.

Hasil penelitian menggambarkan perilaku CTPS dalam kategori cukup $(60,8 \%)$, dengan aspek pengetahuan kategori cukup (56,9\%), sikap kategori cukup (58,8\%) dan tindakan kategori kurang $(58,8 \%)$. Hasil penelitian menggambarkan perilaku pemanfaatan jamban dalam kategori cukup $(62,7 \%)$, dengan aspek pengetahuan kategori cukup $(76,5 \%)$, sikap kategori cukup $(54,9 \%)$ dan tindakan kategori kurang $(51 \%)$.

Disimpulkan aspek pengetahuan, sikap dan tindakan yang telah diberikan bobot dapat menggambarkan perilaku CTPS dalam kategori cukup dan perilaku pemanfaatan jamban dalam kategori cukup. Disarankan bagi masyarakat diperlukan adanya kesadaran akan pentingnya CTPS dan pemanfaatan jamban dalam memutus mata rantai penularan hepatitis A.
\end{abstract}

Kata kunci: Hepatitis A, perilaku CTPS, perilaku pemanfaatan jamban

\section{PENDAHULUAN}

Penyakit menular masih merupakan masalah utama kesehatan masyarakat di Indonesia. Penyakit menular tidak mengenal batas-batas daerah administratif, sehingga pemberantasan penyakit menular memerlukan kerjasama antar daerah, misalnya antar propinsi, kabupaten/kota bahkan antar negara. Beberapa penyakit menular yang menjadi masalah utama di Indonesia adalah diare, malaria, demam berdarah dengue, influenza, tifus abdominalis, penyakit saluran pencernaan dan penyakit lainnya seperti penyakit Hepatitis A (Depkes RI, 2010).

Hepatitis A adalah penyakit menular yang disebabkan oleh virus hepatitis A (VHA) yang bertransmisi melalui fecal-oral, yakni virus masuk ke dalam tubuh ketika seseorang mengonsumsi makanan atau minuman yang terkontaminasi tinja mengandung
VHA. Hepatitis A tergolong penyakit menular yang ringan, sehingga dapat sembuh spontan atau sempurna tanpa gejala sisa, serta tidak menyebabkan infeksi kronis. Hepatitis A sering menyebabkan kejadian luar biasa dalam periode waktu satu hingga dua bulan dengan kecenderungan berulang secara siklik (Kemenkes RI, 2011).

Kejadian hepatitis A merupakan hasil interaksi antara faktor agent, host dan lingkungan. Sesuai teori John Gordon yang dikemukakan pada tahun 1950 suatu penyakit dapat timbul karena terjadi ketidakseimbangan antara penyebab penyakit dengan host (Bustan, 2006). Menurut Harisma, et al (2018) dalam penelitiannya faktor risiko penularan hepatitis A dapat dilihat menurut host dan environment. Segi host ditunjukkan melalui status riwayat kontak dengan penderita dan perilaku host sehari-hari yang dapat mendorong penularan VHA 
secara langsung, serta personal hygiene dari host menyangkut cara mengolah makanan yang tidak memenuhi persyaratan kesehatan dan cuci tangan pakai sabun (CTPS). Segi environment pada penelitian ini berhubungan pada sanitasi lingkungan meliputi kurangnya penyediaan air bersih, pembuangan air limbah dan pengelolaan sampah yang tidak saniter, serta pembuangan tinja yang tidak memenuhi syarat. Faktor risiko tersebut sesuai dengan karakteristik hepatitis A yang berkaitan dengan kondisi lingkungan dan perilaku berisiko (Harisma et al, 2018).

Sarana pembuangan tinja (jamban) merupakan masalah yang penting. Pembuangan tinja secara tidak baik dan sembarangan dapat mengakibatkan kontaminasi pada air, tanah, atau menjadi sumber infeksi, dan akan mendatangkan bahaya bagi kesehatan. Dampak buruk pembuangan tinja yang tidak saniter yaitu penularan penyakit menyangkut transmisi penyakit dari tinja seperti hepatitis $A$, polio, cholera dan lainnya merupakan penyakit yang terkait dengan akses penyediaan jamban. Hal ini sejalan dengan hasil penelitian Aryana et al., (2014) yang menunjukkan pemilikan jamban dan pemanfaatan jamban yang tidak baik sebagai faktor risiko yang berhubungan dengan terjadinya kejadian luar biasa hepatitis A. Penelitian Sari et al., (2018) menunjukkan bahwa dari lima pilar sanitasi, tampak bahwa proporsi penduduk $B A B$ sembarangan yang teridentifikasi menderita hepatitis $\mathrm{A}$ lebih tinggi $(1,7 \%)$ dibandingkan responden yang $B A B$ di jamban $(1,2 \%)$. Penularan hepatitis $\mathrm{A}$ bisa terjadi melalui perantara berbagai media termasuk kotoran yang mengandung virus hepatitis A. Virus hepatitis A yang terdapat pada tinja akan lebih mudah menyebar. Virus Hepatitis A mampu bertahan di tanah dan air pada suhu $25^{\circ} \mathrm{C}$ selama 3 bulan, bertahan 30 hari di tanah yang kering.

Hepatitis A juga dipengaruhi oleh perilaku seseorang. Orang yang berisiko tinggi terkena Hepatitis A antara lain orang yang mengunjungi atau tinggal di daerah endemis Hepatitis $A$, orang yang tinggal di daerah dengan kondisi sanitasi lingkungan yang buruk, orang dengan personal hygiene yang rendah seperti penerapan perilaku hidup bersih dan sehat (PHBS) yang kurang berupa mencuci tangan menggunakan sabun. Hal ini sejalan dengan penelitian Sari et al., (2018) menyebutkan bahwa penduduk yang tidak berperilaku Cuci Tangan Pakai Sabun (CTPS) memiliki risiko 1,7 kali menderita hepatitis A dibandingkan dengan penduduk yang berperilaku CTPS. Menurut penelitian Rahmah \& Indriani (2014) tidak mencuci tangan dengan sabun berhubungan dengan kejadian hepatitis A. Di dalam penelitian Hikmah Laila et al, (2018), orang yang tidak mencuci tangan pakai sabun sehabis $B A B$ mempunyai risiko hepatitis $A$ sebesar 7,9 kali dibanding orang yang cuci tangan pakai sabun sehabis BAB. Menurut Rahmah \& Indriani (2014) virus hepatitis A relatif stabil dan dapat bertahan selama beberapa jam pada ujung jari dalam keadaan kering. Tangan seringkali menjadi agen yang membawa kuman dan menyebabkan patogen berpindah dari satu orang ke orang lain, baik dengan kontak langsung ataupun kontak tidak langsung.

Depkes RI (2014) mencatat, KLB hepatitis A di Indonesia pernah terjadi di berbagai provinsi pada tahun 2013 yakni di Provinsi Riau, Provinsi Lampung, Provinsi Sumatera Barat, Provinsi Jambi, Provinsi Jawa Tengah, dan Provinsi Jawa Timur dengan kasus terbanyak yaitu 287 kasus. Di Jawa Timur, 5 kabupaten dengan angka tertinggi Kabupaten Pasuruan 110 kasus, Kabupaten Lamongan 72 kasus, Kabupaten Pacitan 66 kasus, Kabupaten Ponorogo 25 kasus dan Kabupaten Jombang 14 kasus. Hepatitis A pada tahun 2014 KLB terjadi kembali di Provinsi Sumatera Barat 159 kasus, Provinsi Bengkulu 19 kasus, dan Provinsi Kalimantan Timur 282 kasus.

Pada tahun 2019 kasus hepatitis A

di Kabupaten Trenggalek terjadi peningkatan. Berdasarkan data Dinas Kesehatan Kabupaten Trenggalek, kasus hepatitis A pada tahun 2017 tercatat 203 kasus, tahun 2018 tercatat 263 kasus, tahun 2019 tercatat 430 kasus yang tersebar pada 10 Puskesmas di 8 Kecamatan. Distribusi kasus hepatitis A dari 8 Kecamatan, 249 kasus $(57,6 \%)$ 
berasal dari Kecamatan Panggul. Kepala Bidang P2P Dinas Kesehatan Kabupaten Trenggalek mengatakan bahwa kasus hepatitis A yang terjadi di Kabupaten Trenggalek tidak termasuk dalam kategori KLB. Namun karena hepatitis A merupakan salah satu penyakit yang berpotensi KLB, Dinas Kesehatan Provinsi Jawa Timur telah menurunkan tim surveilans ke Kecamatan Panggul sebagai kecamatan dengan jumlah kasus hepatitis A terbanyak di Kabupaten Trenggalek pada tahun 2019.

Di wilayah Kecamatan Panggul terdapat 2 Puskesmas, yaitu Puskesmas Panggul dengan 193 kasus dan Puskesmas Bodag dengan 55 kasus hepatitis A. Distribusi kasus hepatitis A dari 10 Puskesmas di Kabupaten Trenggalek, 193 kasus (44,9\%) berada di Puskesmas Panggul. Wilayah kerja Puskesmas Panggul terdiri dari 10 desa. Dari 10 desa tersebut, penderita hepatitis A 30,5\% berasal dari Desa Terbis. Perilaku CTPS di desa Terbis $64,5 \%$ dengan target pencapaian $95 \%$ dan cakupan kepemilikan jamban $78,5 \%$, dengan catatan $21,5 \%$ sharing atau menumpang pada jamban tetangga. Hasil survei pendahuluan yang dilakukan oleh peneliti pada bulan Desember tahun 2019 menunjukkan 2 dari 10 responden belum memiliki jamban sendiri dan sharing dengan jamban tetangga. Hal ini menggambarkan bahwa ada kemungkinan 2 responden tersebut bisa melakukan buang air besar sembarangan mengingat desa Terbis berada pada daerah pegunungan sehingga cukup sulit untuk mendapatkan air bersih sebagai sarana pendukung dalam buang air besar dan mencuci tangan.

Sumber air bersih yang digunakan di desa Terbis menggunakan air sumur. Pada saat musim kemarau sumur tersebut mengalami kekeringan sehingga untuk mendapatkan air bersih masyarakat harus membeli untuk mendapatkan air bersih. Sulitnya ketersediaan air bersih ini cenderung mempengaruhi perilaku masyarakat sehingga masyarakat kemungkinan buang air besar sembarangan. Kondisi tersebut hampir sama dengan hasil surveilans di desa Terbis oleh Dinas Kesehatan Provinsi Jawa
Timur dan Puskesmas Panggul pada bulan September yang mengatakan beberapa warga masih sering buang air besar sembarangan, beberapa jamban yang dimiliki warga menggunakan lubang galian dengan penopang papan kayu tanpa adanya penutup sehingga sewaktu hujan lubang tersebut bisa banjir dan mencemari sumber air dan tanah di sekitar.

Pemanfaatan jamban yang kurang baik kemungkinan bisa menjadi penyebab terjadinya hepatitis A. Karena penularannya bisa terjadi melalui perantara berbagai media termasuk tinja yang mengandung virus hepatitis $A$. Selain faktor tersebut, hepatitis A juga dipengaruhi oleh perilaku hidup bersih seperti mencuci tangan untuk meminimalisir kuman di dalam tinja terbawa oleh tangan dan berpindah ke media lainnya, seperti makanan dan minuman.

Penelitian ini bertujuan untuk menggambarkan perilaku cuci tangan pakai sabun (CTPS) dan pemanfaatan jamban pada penderita Hepatitis A di Desa Terbis Kecamatan Panggul Kabupaten Trenggalek Tahun 2020.

\section{METODE PENELITIAN}

Desain penelitian ini adalah deskriptif yaitu menggambarkan perilaku cuci tangan pakai sabun (CTPS) dan pemanfaatan jamban pada penderita Hepatitis A di Desa Terbis Kecamatan Panggul Kabupaten Trenggalek.

Populasi dalam penelitian ini adalah seluruh penderita hepatitis A di Desa Terbis Kecamatan Panggul Kabupaten Trenggalek dengan jumlah 59 responden. Sampel yang diambil adalah seluruh penderita Hepatitis A yang berumur 10 tahun ke atas sejumlah 51 sampel yang dipilih menggunakan Teknik purposive sampling.

Teknik analisis data dengan menggunakan analisis deskriptif, yaitu analisis dalam bentuk frekuensi, tabel dan narasi dalam memaknai setiap variabel yang diteliti. 
HASIL DAN PEMBAHASAN

Tabel 1

DATA KARAKTERISTIK RESPONDEN PENDERITA HEPATITIS A DI DESA TERBIS KECAMATAN PANGGUL KABUPATEN TRENGGALEK TAHUN 2020

\begin{tabular}{|c|c|c|c|}
\hline No & Jenis Variabel & Frekuensi (n) & Prosentase \% \\
\hline \multirow[t]{7}{*}{1} & Usia & & \\
\hline & a. 10-19 tahun & 10 & 19,6 \\
\hline & b. 20-29 tahun & 10 & 19,6 \\
\hline & c. 30-39 tahun & 14 & 27,5 \\
\hline & d. $40-49$ tahun & 9 & 17,6 \\
\hline & e. 50-59 tahun & 8 & 15,7 \\
\hline & Total & 51 & 100 \\
\hline \multirow[t]{4}{*}{2} & Jenis Kelamin & & \\
\hline & a. Laki - laki & 31 & 60,8 \\
\hline & b. Perempuan & 20 & 39,2 \\
\hline & Total & 51 & 100 \\
\hline
\end{tabular}

Hasil penelitian menunjukkan bahwa dari 51 responden distribusi usia yang paling banyak yaitu pada rentang usia 30-39 tahun (27,5\%) dan distribusi usia responden yang paling sedikit memiliki rentang usia 50-59 tahun
(15,7\%). Dari 51 responden menunjukkan responden dengan jenis kelamin laki-laki memperoleh jumlah tertinggi yaitu sebanyak 60,8\%, sedangkan responden dengan jenis kelamin perempuan sebanyak 39,2\%.

Tabel 2

DATA PERILAKU CUCI TANGAN PAKAI SABUN (CTPS) PENDERITA HEPATITIS A DI DESA TERBIS KECAMATAN PANGGUL KABUPATEN TRENGGALEK TAHUN 2020

\begin{tabular}{|c|c|c|c|}
\hline No & Jenis Variabel & Frekuensi (n) & Prosentase \% \\
\hline \multirow[t]{5}{*}{1} & Tingkat Pengetahuan & & \\
\hline & a. Baik & 0 & 0 \\
\hline & b. Cukup & 29 & 56,9 \\
\hline & c. Kurang & 22 & 43,1 \\
\hline & Total & 51 & 100 \\
\hline \multirow[t]{5}{*}{2} & Sikap & & \\
\hline & a. Baik & 16 & 31,4 \\
\hline & b. Cukup & 30 & 58,8 \\
\hline & c. Kurang & 5 & 9,8 \\
\hline & Total & 51 & 100 \\
\hline \multirow[t]{5}{*}{3} & Tindakan & & \\
\hline & a. Baik & 3 & 5,9 \\
\hline & b. Cukup & 18 & 35,3 \\
\hline & c. Kurang & 30 & 58,8 \\
\hline & Total & 51 & 100 \\
\hline \multirow[t]{5}{*}{4} & Perilaku CTPS & & \\
\hline & a. Baik & 6 & 11,8 \\
\hline & b. Cukup & 31 & 60,8 \\
\hline & c. Kurang & 14 & 27,4 \\
\hline & Total & 51 & 100 \\
\hline
\end{tabular}


Hasil penelitian menunjukkan bahwa responden mempunyai perilaku CTPS kategori cukup sebanyak 31 responden $\quad(62,7 \%)$, sedangkan responden yang menggambarkan perilaku CTPS kategori kurang sebanyak 14 responden $(27,4 \%)$ dan kategori baik sebanyak 6 responden $(11,8 \%)$.

Dari hasil pengumpulan data melalui kuesioner didapatkan bahwa $29,4 \%$ responden tidak tahu mencuci tangan dapat mencegah penularan hepatitis A. Penyelidikan epidemiologi KLB Hepatitis A di pedesaan China menyatakan bahwa kebiasaan cuci tangan merupakan faktor risiko terjadinya Hepatitis A walaupun bukan merupakan faktor utama (Yu et al., 2015). Penelitian Sari et al. (2018), penduduk yang tidak berperilaku CTPS berisiko $1,9 \%$ menderita penyakit Hepatitis A dibandingkan dengan mereka yang sudah berperilaku cuci tangan pakai sabun. Mencuci tangan dengan air bersih yang mengalir dan sabun merupakan salah satu cara untuk memutus mata rantai penyebaran mikroorganisme sehingga terhindar dari risiko terkena penyakit, khususnya Hepatitis A (Rohmah, 2016).

Dari hasil penelitian menunjukkan $56,7 \%$ responden tidak tahu urutan langkah mencuci tangan yang benar. Langkah-langkah CTPS yang benar sesuai dengan Permenkes RI No. 03 tahun 2014 tentang Sanitasi Total Berbasis Masyarakat sebagai berikut:

1. Basahi kedua tangan dengan air bersih yang mengalir.

2. Gosokkan sabun pada kedua telapak tangan sampai berbusa lalu gosok kedua punggung tangan, jari jemari, kedua jempol, sampai semua permukaan kena busa sabun.

3. Bersihkan ujung-ujung jari dan selasela di bawah kuku.

4. Bilas dengan air bersih sambil menggosok-gosok kedua tangan sampai sisa sabun hilang.

5. Keringkan kedua tangan dengan memakai kain, handuk bersih, atau kertas tisu, atau mengibas-ibaskan kedua tangan sampai kering (Kemenkes RI, 2014).
Penelitian ini menunjukkan seluruh responden tahu mencuci tangan dilakukan di air yang mengalir, tetapi $35,3 \%$ responden tidak tahu mencuci tangan menggunakan sabun, dan seluruh responden tidak tahu mencuci tangan dilakukan selama 20 detik. Perlu diketahui bahwa mencuci tangan yang benar menurut Permenkes RI No. 3 tahun 2014 tentang Sanitasi Total Berbasis Masyarakat, Cuci Tangan Pakai Sabun (CTPS) adalah perilaku cuci tangan secara benar dengan menggunakan air bersih yang mengalir dan sabun selama 20 detik (Kemenkes RI, 2014).

Pengetahuan yang kurang pada responden dapat mengakibatkan responden bersikap dan berperilaku kurang tepat dalam mencuci tangan pakai sabun sehingga virus masih menempel di tangan dan dapat menularkan Hepatitis A. Virus hepatitis A ditularkan terutama melalui fecal-oral transmission. Hal tersebut dapat terjadi saat orang menelan makanan atau air yang telah terkontaminasi kotoran orang yang terinfeksi (WHO, 2017). Sama dengan pemanfaatan jamban, minimnya informasi yang mereka dapat tentang sanitasi lingkungan terutama tentang jamban sehat. Yang mereka pahami hanyalah tidak diperbolehkan BAB di sembarang tempat, tanpa memikirkan persyaratan kesehatan yang harus dipenuhi oleh sarana jamban keluarga tersebut. Hal ini menyebabkan responden hanya membangun sarana tanpa memikirkan aspek-aspek persyaratan kesehatan.

Dari penelitian didapatkan 56,9\% responden tidak menyediakan sarana cuci tangan yang dilengkapi air mengalir. Responden tersebut menyediakan air di dalam bak penampung (ember) yang digunakan berulang. 54,9\% responden tidak menyediakan sarana cuci tangan yang dilengkapi dengan sabun dan $9,8 \%$ responden tidak menyediakan sarana cuci tangan yang dilengkapi dengan saluran pembuangan air limbah. Hal ini sama dengan penelitian Simbolon \& Simorangkir (2018) yang menyebutkan kurang terbentuknya kebiasaan CTPS disebabkan karena tidak tersedianya 
fasilitas CTPS. 27,5\% responden tidak mengeringkan tangan dengan kain bersih setelah mencuci tangan. Kebersihan tangan yang baik juga harus mencakup dengan pengeringan tangan secara menyeluruh, tidak hanya dengan mencuci. Selain itu dengan sisa-sisa air yang berada di tangan akan mengakibatkan tangan basah sehingga transmisi virus lebih mungkin terjadi dari tangan yang basah daripada tangan yang kering.

Hasil penelitian menunjukkan $60,8 \%$ responden tidak mencuci tangan menggunakan sabun sebelum makan, $88,2 \%$ responden tidak mencuci tangan menggunakan sabun sebelum mengolah dan menghidangkan makanan, $88,2 \%$ responden tidak mencuci tangan menggunakan sabun sebelum memberi makan bayi/balita, dan $72,6 \%$ responden tidak mencuci tangan menggunakan sabun setelah BAB. Dengan catatan responden hanya mencuci tangan menggunakan air saja, tanpa menggunakan sabun. Perilaku mencuci tangan yang dilakukan responden hanyalah mencuci tangan dengan air sehingga tidak efektif untuk membunuh
VHA. Mencuci tangan dengan menggunakan sabun antiseptik merupakan salah satu upaya pencegahan yang dapat dilakukan untuk menghindari penularan VHA (Kemenkes RI, 2012). Penelitian Sari et al., (2018) mengatakan bahwa penduduk yang tidak berperilaku CTPS berisiko 1,9\% menderita penyakit hepatitis A dibandingkan dengan mereka yang sudah berperilaku CTPS, demikian pula menurut penelitian Rahmah \& Indriani (2014) tidak mencuci tangan dengan sabun berhubungan dengan kejadian hepatitis $A$.

Virus hepatitis A berada di sekitar kita dan dapat menempel di tangan. Jika tangan tidak dicuci menggunakan sabun sebelum makan atau sebelum mengolah makan atau sesudah buang air besar, maka virus tersebut dapat masuk ke dalam tubuh baik melalui makanan atau minuman. Hal ini dikarenakan virus dapat bertahan selama beberapa jam pada ujung jari dan tangan dalam keadaan kering, terlebih jika tidak terbiasa mencuci tangan pakai sabun sehingga mencemari makanan atau minuman hingga tertelan (Rahmah \& Indriani, 2014)

Tabel 3

DATA PERILAKU PENGGUNAAN JAMBAN PENDERITA HEPATITIS A DI DESA TERBIS KECAMATAN PANGGUL KABUPATEN TRENGGALEK TAHUN 2020

\begin{tabular}{|c|c|c|c|}
\hline No & Jenis Variabel & Frekuensi (n) & Prosentase \% \\
\hline \multirow[t]{5}{*}{1} & Tingkat Pengetahuan & & \\
\hline & a. Baik & 12 & 23,5 \\
\hline & b. Cukup & 39 & 76,5 \\
\hline & c. Kurang & 0 & 0 \\
\hline & Total & 51 & 100 \\
\hline \multirow[t]{5}{*}{2} & Sikap & & \\
\hline & a. Baik & 23 & 45,1 \\
\hline & b. Cukup & 28 & 54,9 \\
\hline & c. Kurang & 0 & 0 \\
\hline & Total & 51 & 100 \\
\hline \multirow[t]{5}{*}{3} & Tindakan & & \\
\hline & a. Baik & 17 & 33,3 \\
\hline & b. Cukup & 8 & 15,7 \\
\hline & c. Kurang & 26 & 51 \\
\hline & Total & 51 & 100 \\
\hline \multirow[t]{5}{*}{4} & Perilaku Pemanfaatan jamban & & \\
\hline & a. Baik & 19 & 37,3 \\
\hline & b. Cukup & 32 & 62,7 \\
\hline & c. Kurang & 0 & 0 \\
\hline & Total & 51 & 100 \\
\hline
\end{tabular}


Hasil penelitian menunjukkan bahwa responden mempunyai perilaku pemanfaatan jamban dengan kategori cukup sebanyak 32 responden $(62,7 \%)$, sedangkan responden yang menggambarkan perilaku pemanfaatan jamban kategori baik sebanyak 19 responden (37,3\%).

Dari hasil pengumpulan data melalui kuesioner didapatkan bahwa seluruh responden sudah tahu jamban adalah tempat membuang atau menampung kotoran, sarana dasar yang harus dimiliki oleh setiap keluarga dan perilaku memanfaatkan jamban yang harus dilakukan oleh setiap anggota keluarga setiap BAB. Menurut Tarigan (2008), jamban keluarga merupakan bagian yang penting dalam rumah tangga karena dapat mencegah berkembangnya penyakit infeksius yang berasal dari tinja manusia seperti Hepatitis A. Penggunaan jamban memiliki efek yang besar bagi penurunan risiko penularan penyakit dan setiap anggota keluarga harus buang air besar di jamban. Penelitian yang dilakukan Aryana et al., (2014) yang menyatakan bahwa ada hubungan antara perilaku BAB dengan kejadian Hepatitis A. Begitu pula dengan penelitian Sari et al., (2018) bahwa proporsi responden yang $B A B$ sembarangan teridentifikasi menderita Hepatitis A lebih tinggi (1,7\%) dibandingkan dengan reponden yang BAB di jamban $(1,2 \%)$.

Dari hasil penelitian didapatkan $49 \%$ responden tidak tahu jarak sumber air bersih dengan resapan pembuangan lebih dari 10 meter dan $45 \%$ responden tidak tahu penularan Hepatitis A dapat dicegah dengan membiasakan menggunakan jamban setiap BAB. Kebersihan jamban akan mempengaruhi terjadinya penularan Hepatitis A (Leoni, 2008). Jamban yang dijaga kebersihannya menjadi saniter. Jamban yang saniter menurunkan risiko penularan Hepatitis A (Kemenkes RI, 2014).

Dari hasil penelitian didapatkan bahwa $11,8 \%$ responden tidak memiliki jamban keluarga dan 4\% responden tidak selalu memanfaatkan jamban setiap $B A B$. Rumah tangga yang menggunakan jamban yang memenuhi syarat dan sehat untuk buang air kecil dan besar mempunyai risiko lebih kecil bagi anggota keluarga untuk tertular penyakit (Rohmah, 2016). Penelitian Aryana et al., (2014) menunjukkan bahwa kejadian luar biasa hepatitis A terjadi karena pemanfaatan jamban yang rendah dan ada hubungan antara kepemilikan jamban dengan kejadian Hepatitis A. Penyebaran penyakit hepatitis A melalui jalur fecal-oral dan sangat dipengaruhi oleh keadaan sanitasi termasuk kepemilikan jamban dan pemanfaatannya. Kepemilikan jamban di rumah akan membuat kecenderungan responden untuk $B A B$ di rumah akan besar sehingga menurunkan risiko transmisi Hepatitis A. Apabila tidak memiliki jamban, maka responden akan cenderung $B A B$ di kebun. Jika salah satu yang BABS adalah penderita Hepatitis $A$ maka ia berisiko untuk menularkan Hepatitis A.

Hasil penelitian menunjukkan $66,7 \%$ responden tidak menyediakan air bersih di dalam jamban dan tidak menyediakan sabun di dalam jamban. Sehingga terdapat kemungkinan responden tersebut tidak mencuci tangan dengan air bersih dan sabun setelah BAB. Selaras dengan penelitian yang dilakukan oleh Ropiah (2013) melaporkan bahwa orang dengan tidak mencuci tangan pakai sabun setelah BAB 2,7 kali mengalami kejadian hepatitis $A$. Begitu pula dengan penelitian yang dilakukan Hikmah Laila et al., (2018), orang yang tidak cuci tangan pakai sabun sehabis BAB mempunyai risiko kejadian Hepatitis A sebesar 7,90 kali dibanding orang yang cuci tangan pakai sabun sehabis BAB. Kemenkes RI (2012) menyatakan bahwa perilaku mencuci tangan dengan sabun setelah BAB merupakan salah satu upaya pencegahan penularan hepatitis $A$. Tangan yang bersentuhan langsung dengan kotoran manusia dan binatang, ataupun cairan tubuh lain yang terkontaminasi saat tidak dicuci dengan sabun dapat memindahkan bakteri, virus dan parasit termasuk Virus Hepatitis A pada orang lain yang tidak sadar bahwa dirinya sedang ditularkan (Anung, 2015). 
Pengumpulan data lainnya didapatkan $62,7 \%$ responden tidak membersihkan jamban minimal 2-3 kali seminggu, 52,9\% responden tidak memiliki atap pada bangunan jamban, $29,4 \%$ responden tidak memiliki dinding pada bangunan jamban, $55 \%$ responden lantai jamban tidak terbuat dari bahan kedap air dan licin, 7,8\% responden lubang penampungan tinja kurang dari 10 meter dari sumber air, $64,7 \%$ responden jamban tidak bersih dan berbau. $60,8 \%$ responden kontruksi jamban memungkinkan serangga masuk ke lubang jamban. Hal tersebut tidak sesuai dengan syarat pembangunan jamban sehat.

Penelitian Firdous (2012) memberikan hasil bahwa, responden yang keadaan jambannya tidak memenuhi syarat berpeluang sakit Hepatitis A sebesar 10,6 kali lebih besar dibanding responden yang keadaan jambannya memenuhi syarat. Sari et al., (2018) menjelaskan bahwa penduduk dengan akses sanitasi yang tidak layak lebih banyak yang menderita hepatitis yaitu sebesar $1,7 \%$ dibandingkan mereka yang mempunyai akses sanitasi layak $(1,1 \%)$. Sanitasi layak (improved) apabila sarana $B A B$ milik sendiri, jenis tempat BAB merupakan leher angsa atau plengsengan serta tempat pembuangan akhir tinja berupa tanki septic atau SPAL (WHO \& UNICEF, 2006). Pembuangan tinja yang tidak sesuai aturan akan mempermudah penyebaran penyakit yang dapat menular melalui feses, seperti Hepatitis A. Penyebaran penyakit yang bersumber dari feses dapat melalui beberapa cara. Pembuangan tinja yang salah akan mencemari air, tanah, dan dapat menempel pada vektor penyebab penyakit. Sumber air yang tercemar tinja dapat mencemari makanan, dan selanjutnya makanan atau air tersebut dikonsumsi oleh manusia. Dengan pemanfaatan jamban yang memenuhi syarat maka masyarakat dapat terhindar dari penyakit yang dapat ditimbulkan akibat jamban yang tidak sehat, karena banyaknya faktor pembawa penyakit yang barada pada jamban yang tidak memenuhi syarat (Azwar, 2003).
Pembuangan tinja menjadi hal penting dalam penyebaran Hepatitis A. Hal ini mengingat karena penularan Hepatitis A terjadi secara fecal-oral. Ini artinya virus Hepatitis A keluar dari orang yang terinfeksi melalui kotoran manusia dan masuk ke tubuh orang lain melalui makanan atau minuman yang terkontaminasi kotoran manusia. Oleh karena itu, upaya yang perlu dilakukan adalah dengan menyediakan sarana pembuangan tinja yang memenuhi syarat agar tidak terjadi pencemaran air di sekitarnya. Kondisi pembuangan kotoran yang tidak memenuhi syarat menyebabkan lalat berkerumun dan pada gilirannya akan memindahkan kuman pathogen ke makanan atau minuman. Virus sudah dapat ditemukan pada tinja sejak 3 hari sebelum muncul gejala sehingga penderita tidak menyadari dirinya sudah bisa menularkan HAV meskipun secara fecal-oral (Kemenkes RI, 2012).

Menurut Notoatmodjo (2012), tindakan merupakan penilaian atau pendapat terhadap apa yang diketahui, proses selanjutnya akan melaksanakan atau mempraktikan apa yang diketahui atau disikapinya. Sikap belum tentu terwujud dalam tindakan, sebab untuk terwujudnya tindakan perlu faktor lain, yaitu antara lain adanya fasilitas atau sarana dan prasarana. Fasilitas merupakan suatu faktor pendukung pemanfaatan jamban yang baik. Oleh karena itu perlu tersedianya fasilitas yang mencukupi, karena tanpa adanya fasilitas maka kebiasaan perilaku CTPS dan pemanfaatan jamban tidak dapat dilakukan. Akan tetapi, kurangnya pendapatan keluarga menjadi faktor tidak tersedianya fasilitas pendukung dalam pemanfaatan jamban yang memenuhi syarat kesehatan, faktor ketersediaan air bersih mempengaruhi perilaku masyarakat dalam perilaku CTPS, faktor pengetahuan juga merupakan faktor pendukung dalam tersedianya fasilitas CTPS dan pemanfaatan jamban.

\section{KESIMPULAN}

Penelitian ini dapat disimpukan bahwa perilaku CTPS pada penderita hepatitis A 
di Desa Terbis Kecamatan Panggul Kabupaten Trenggalek pada tahun 2020, yang berkategori baik hanya $13,7 \%$, sedangkan perilaku pemanfaatan jamban dengan kategori baik hanya $37,3 \%$.

\section{SARAN}

Penelitian ini menunjukkan bahwa masyarakat ekonomi rendah masih memerlukan akses air bersih, fasilitas cuci tangan dan pembuangan tinja, serta masih diperlukan kegiatan promosi kesehatan dari petugas kesehatan untuk meningkatkan perilaku saniter dalam memutus mata rantai penularan hepatitis A dengan membiasakan perilaku CTPS dan BAB di jamban.

\section{DAFTAR PUSTAKA}

Anung. (2015). Kesehatan Dalam Kerangka.

http://www.pusat2.litbang.depkes. go.id/SDGs.pdf

Aryana, I. G. K., Ngurah, I. G., Putra, S., \& Karyana, I. P. G. (2014). Risk Factors of Hepatitis a Outbreak in Students At Elementary Schools. Jurnal I/miah Kedokteran, 79-84.

Azwar, A. (2003). Pengantar Administrasi Kesehatan. Mutiara Sumber Widya.

Bustan, M. N. (2006). Pengantar Epidemiologi. PT. Asdi Mahasatya.

Depkes RI. (2010). Hepatitis Masalah Kesehatan

Dunia.

http://www.depkes.go.id/article/vi ew/1110/hepatitis-masalahkesehatan-dunia.html

Depkes RI. (2014). Infodatin: Situasi Dan Analisa Hepatitis. http://www.depkes.go.id/resources /download

Firdous, U. (2012). Cuci Tangan Sebelum Makan Menurunkan Risiko Kejadian Hepatitis Akut Klinis. Buletin Penelitian Kesehatan, 33(3), 121131.

Harisma, F. B., Syahrul, F., Mubawadi, T., \& Mirasa, Y. A. (2018). Analisis Kejadian Luar Biasa Hepatitis a Di Sma X Kabupaten Lamongan Tahun 2018. Jurnal Berkala Epidemiologi, 6 Nomor 2, 112-121. https://doi.org/10.20473/jbe.v6i2.2 018
Hikmah Laila, N., Mahkota, R., Sariwati, E., \& Agus Setiabudi, D. (2018). Faktor Risiko Terjadinya Kejadian Luar Biasa (KLB) Hepatitis A di Kabupaten Tangerang Tahun 2016. Jurnal Epidemiologi Kesehatan Indonesia, 2(1), 1-6.

Kemenkes RI. (2011). Buku Pedoman Penyelidikan Dan Penanggulangan Kejadian Luar Biasa Penyakit Menular Dan Keracunan Pangan (Pedoman Epidemiologi Penyakit). Ditjen PP \& PL Kementerian Kesehatan Republik Indonesia.

Kemenkes RI. (2012). Pedoman Pengendalian Hepatitis Virus. Ditjen PP \& PL Kementerian Kesehatan Republik Indonesia.

Kemenkes RI. (2014). Peraturan Menteri Kesehatan Republik Indonesia No. 03 Tahun 2014 Tentang Sanitasi Total Berbasis Masyarakat. Kementerian Kesehatan Republik Indonesia.

Notoatmodjo, S. (2012). Promosi Kesehatan Dan Perilaku Kesehatan. Rineka Cipta.

Rahmah, S., \& Indriani, C. (2014). Hubungan Faktor Perilaku Dengan Kejadian Hepatitis A di Kecamatan Depok Kabupaten Sleman. Jurnal Media Kesehatan Masyarakat Indonesia, 10(1), 16-20.

Rohmah, N. (2016). Hubungan Antara PHBS, Penggunaan Air Bersih Dan Jamban Sehat Di Rumah Tangga Dengan Kejadian Diare Pada Balita Di Wilayah Kerja Puskesmas Sekardangan Kabupaten Sidoarjo. Universitas Airlangga Surabaya.

Ropiah et al. (2013). Faktor Lingkungan Dan Perilaku Yang Berhubungan Dengan Kejadian Hepatitis A Di Kecamatan Sintang Kabupaten Sintang. Jurnal Kesmas Unmuhpnk, 21.

Sari, P., Azhar, K., Pradono, J., \& Sukoco, N. E. W. (2018). Hubungan Perilaku Cuci Tangan, Pengelolaan Air Minum Dan Rumah Sehat Dengan Kejadian Hepatitis Di Indonesia. Jurnal Ekologi Kesehatan, 171), 41-51.

https://doi.org/10.22435/jek.17.1. 139.41-51 
Simbolon, P., \& Simorangkir, L. (2018). Penerapan UKS dengan PHBS di Wilayah Kerja Puskesmas Pancur Batu Kabupaten Deli Serdang. Jurnal Kesehatan Lingkungan Indonesia, 17(1), 16-25. https://doi.org/10.14710/jkli.17.1.1 6-25

Tarigan, E. (2008). Faktor-Faktor Yang Mempengaruhi Partisipasi Keluarga Dalam Penggunaan Jamban Di Kota Kabanjahe. Universitas Sumatera Utara.

WHO. (2017). Global Hepatitis Report. http://www.who.int/hepatitis/publi cations/global-hepatitisreport2017/en/

WHO, \& UNICEF. (2006). Meeting The MDG Drinking Water And Sanitation Target The Urban And Rural Challange of The Decade. http://www.washdate.org/reports 